\title{
Bolivia: Marketing and economic analyses help NGOs develop strategies for sustainability
}

Frontiers in Reproductive Health

Follow this and additional works at: https://knowledgecommons.popcouncil.org/departments_sbsr-rh

Part of the Community Health and Preventive Medicine Commons, Demography, Population, and Ecology Commons, Family, Life Course, and Society Commons, Health Services Research Commons, International Public Health Commons, and the Medicine and Health Commons How does access to this work benefit you? Let us know!

\section{Recommended Citation}

"Bolivia: Marketing and economic analyses help NGOs develop strategies for sustainability," FRONTIERS OR Summary no. 61. Washington, DC: Population Council, 2007. 


\section{Bolivia \\ Sustainability}

OR Summary 61

\section{Marketing and Economic Analyses Help NGOs Develop Strategies for Sustainability}

Marketing and economic analyses conducted by three Bolivian nongovernmental reproductive health service organizations (NGOs) measured service costs, client attitudes toward services, and market advantages relative to competitors. Such analysis is critical for identifying opportunities to increase the sustainability of services.

\section{Background}

Many nongovernmental organizations (NGOs) face reduced funding for reproductive health services. In response, NGOs are seeking ways to assess and enhance their ability to generate income to cover their service costs. In 2004, following a workshop on financial sustainability presented by the Population Council's FRONTIERS Program, three Bolivian NGOs - Prosalud, the Center for Research, Education, and Services or CIES, and the Association of Rural Health Programs or APSAR - developed operations research studies to improve their financial sustainability.

The Prosalud and CIES studies included a cost recovery study, a study measuring clients' willingness to pay for services (WTP), and a market segmentation study to compare the NGOs' services with those of local competitors. The APSAR study focused specifically on assessing costs and cost recovery.

The three NGOs collected cost data for major services including general medicine, gynecology, family planning, pediatrics, ophthalmology (Prosalud only), and ultrasound. Data gathering for the costing studies included assessments of the cost of labor, durable clinic equipment (capital costs), and supplies, and comparison of client fees with these costs. In the WTP studies, researchers assessed clients' willingness to pay for increases in fees for selected services, and projected changes in revenue based on these responses. The market segmentation study compared aspects of the NGO clinics (services, prices, hours of availability, and amenities such as appearance and comfort) with those of nearby public, NGO, and private clinics that provided the same services.

\section{Findings}

- Cost recovery: These studies measured both financial costs (actual program expenditures) and nonfinancial costs (all resources, regardless of who pays for the resources), and compared them with client fees.

- Prosalud overall was closest to full sustainability. Service fees covered most of its costs (between $83 \%$ and $109 \%$, depending on the service). This did not include family planning services, which are provided free of charge in accordance with Prosalud policy.

- Cost recovery at CIES and APSAR was much lower. Service fees at CIES covered less than half of costs ( $38 \%$ to $46 \%)$, while cost recovery at APSAR was only $10-25$ percent.

WTP studies: Exit interviews with about 3,600 Prosalud clients and 1,100 CIES clients were used to assess willingness to pay more for specific services. 
- Average prices surveyed ranged from about Bs 18 (US\$2.25) for adolescent services at CIES to Bs 27 (\$3.38) for gynecology services at Prosalud, with a peak price of Bs 37 (\$4.60) for ultrasound services at CIES.

- Clients resoundingly rejected the idea of price increases. The WTP study showed that even small increases in prices would trigger large declines in demand, resulting in lower total revenues.

Market segmentation study: Staff from participating clinics at both Prosalud and CIES identified nearby clinics belonging to the Ministry of Health $(\mathrm{MOH})$, other NGOs, and private practitioners that might serve clients of similar socioeconomic status.

-Prosalud's prices, hours, and amenities were comparable to those of clinics in the private forprofit sector, perhaps explaining Prosalud clients' unwillingness to pay higher prices. Both featured relatively high prices, more convenient hours, and attractive amenities. While other NGOs are likely to serve clients for whom lower prices were priorities, Prosalud and the for-profit sector probably compete for clients who will pay more for convenience and amenities.

- CIES prices were higher than those charged by the $\mathrm{MOH}$, but lower than those of NGO and private competitors. Average ratings of amenities and service hours were somewhat lower than those of competing clinics.

\section{Increasing sustainability}

- It is unlikely that Prosalud will increase sustain- ability through increased users or higher prices. Alternatives include reducing costs, investing in new profitable services, or developing new approaches that will increase service use by existing clients.

- Cost control would be the first priority for CIES. One option might be to make more intensive use of fixed resources.

- APSAR has few opportunities to reduce costs or increase prices. Given its rural location, the dispersed clientele, and clients' limited economic means, APSAR will likely continue to require donor subsidies for its reproductive health programs.

\section{Utilization}

- Based on the study findings, Prosalud planned to test a strategy for offering existing clients a new service: sales of low-priced generic drugs as part of a package of curative services. Additionally, Prosalud will develop capacity in break-even analysis, and plans to expand training in cost analysis to its regional offices.

- CIES incorporated their study findings into their regional business plans. The major benefit of the research for APSAR has been the development of staff capacity to conduct costing estimates for improved financial planning.

\section{Policy Implications}

- Marketing and economic analysis techniques are critical tools for NGOs seeking to understand their true costs, improve their cost recovery, and enhance sustainability in an era of continuing cost constraints.

February 2007

Source: Mérida, Martha et al. 2006. "Operations research to improve financial sustainability of three Bolivian NGOs,” FRONTIERS Final Report. Washington, DC: Population Council. Available on our website at www.popcouncil.org/frontiers/finalreports.html or by e-mail: frontiers@pcdc.org

This publication is made possible by the generous support of the American people through the United States Agency for International Development (USAID) under the terms of Cooperative Agreement No. HRN-A-00-98-00012-00. The contents are the responsibility of the FRONTIERS Program and do not necessarily reflect the views of USAID or the United States Government. 